\title{
Congenital Bilateral ocular hypoplasia associated with bilateral manifestation of Klippel- Trenaunay- Weber syndrome of the lower extremities: uncommon presentation in a Bulgarian patient with dermatitis hypostatica!
}

\author{
Ivanka Temelkova ${ }^{1}$, Georgi Tchernev ${ }^{1 *}$ \\ ${ }^{1}$ Onkoderma-Clinic for Dermatology, Venereology and Dermatologic Surgery, General Skobelev 26, 1606 Sofia.
}

Received: October 08, 2019; Accepted: October 08, 2019; Published: October 11, 2019

*Corresponding author: Prof Dr. Georgi Tchernev, Onkoderma-Clinic for Dermatology, Venereology and Dermatologic Surgery, General Skobelev 26, 1606 Sofia; E-mail: georgi_tchernev@yahoo.de

We present a 40 year old man with anamnestic / documentary evidence of Klippel-Trenaunay-Weber syndrome (KTWS) and congenital bilateral ocular hypoplasia. The reason for hospitalisation is the patient's complaint about the recurrence of very painful lesions at the skin of the two lower limbs dating back to 2015. The last deterioration is in the last 14 days, with swelling, redness and secretion appearing in the area of the lower legs
(Fig.1a-b). Within the clinical examination, in parallel with the erosive ones, pretibially and laterally localized cutaneous changes of the lower limbs: in the form of post- and hyperpigmentations, massive eczematization and multiple erosions (Figs. 1a-1b), clinical evidence of bilateral ocular hypoplasia (Fig. 1c) was also established (in addition to the anamnestic).
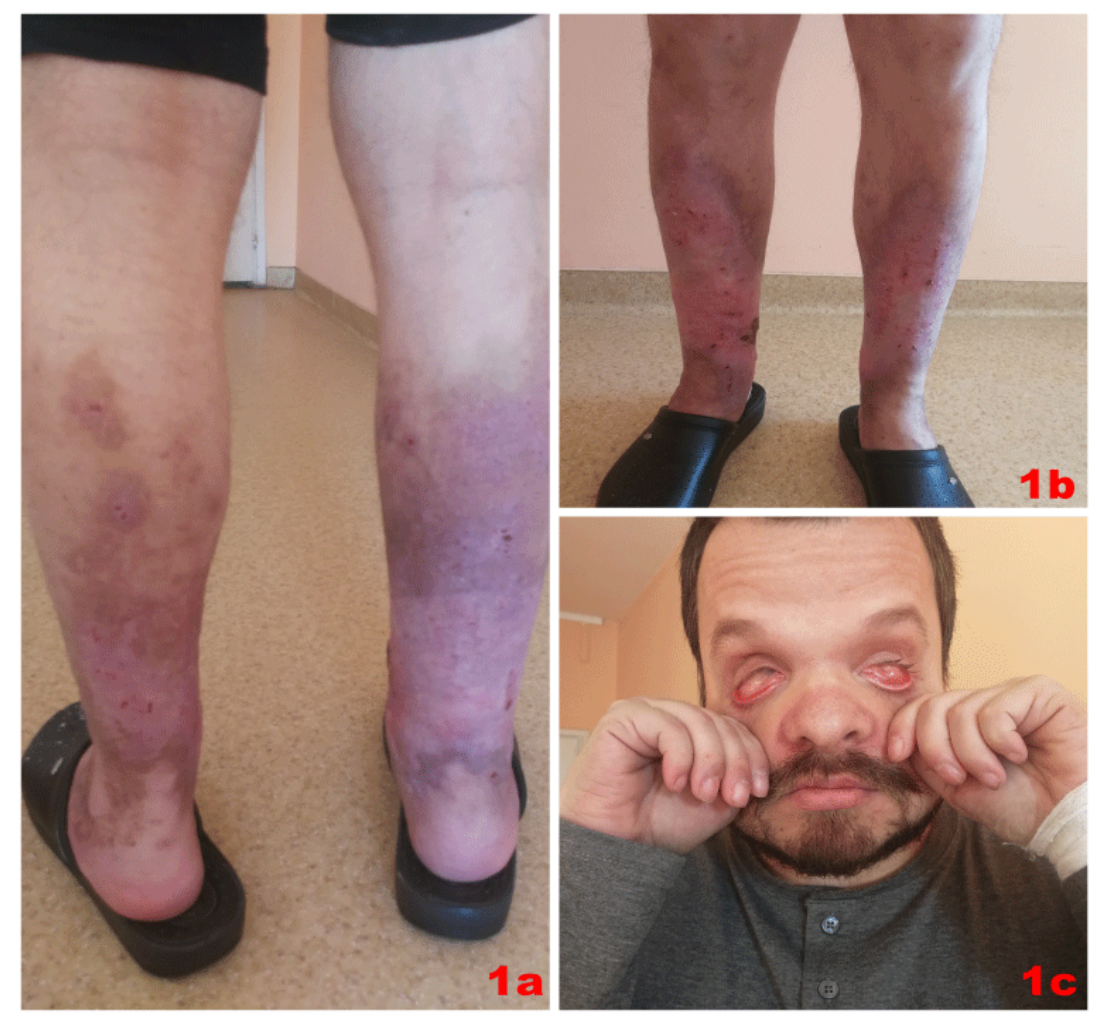

Figure. 1a- b: cutaneous changes of the lower limbs in the form of post- and hyperpigmentations, massive eczematization and multiple erosions. Figure. 1c: clinical data for bilateral ocular hypoplasia. 
For 10 years, the patient has been diagnosed in the Vascular Surgery Clinic with Klippel-Trenaunay- Weber Syndrome, with the presence of an arteriovenous fistula, on the occasion of which embolisation was first performed in 2006 with the placement of metal shunts through a. peronea sinistra. Between 2006 and 2017 the patient underwent 6 lower extremity embolisations, the last one in 2017. At the time of hospitalisation, there was no evidence of vascular nevus in the lower / upper extremities, trunk and face, varicose veins and soft tissue and / or bone hypertrophy. Pretibial hyperpigmentation and perilesional erythema were observed as a possible post-therapeutic outcome of past embolization (Fig. $1 a-b)$.

S. aureus, sensitive to antibiotic therapy with Ceftriaxone 2 g / day i.v for 7 days, was isolated from the skin rub. Systemic antihistamine therapy with Desloratidine $5 \mathrm{mg} /$ day p.o. was performed alongside due to complaints of severe itching. On a daily basis, iodasept ointment dressings and potassium permanganate compressions x 2 / day were applied, and silver sulfadiazine x 2 / day for 7 days was also administered. Good clinical response to skin changes was observed. Prophylactically, nadroparin calcium $0.4 \mathrm{ml} /$ s.c.was also applied.
The Klippel-Trenaunay Syndrome (KTS) is considered to be a congenital type of disease, which in most cases is manifested by triad of port-wine stains, bone or soft tissue hypertrophy, or both, and venous and / or lymphatic malformation [1]. As two of the three manifestations are necessary for the diagnosis of KTS [1]. In cases where arteriovenous malformation is observed (as in the patient described by us), the condition is assigned to the so-called Klippel-Trenaunay-Weber syndrome (KTWS) [2]. Both syndromes are thought to result from somatic mutations involving genes responsible for embryonic angiogenesis [1]. The first gene identified for Klippel-Trenaunay syndrome (KTS) is Aggf1 which is essential for both physiological angiogenesis and pathological tumour angiogenesis in vivo [3]. The potential for a mechanistic link between AGGF1 and PIK3CA, the two genes identified for KTS, located in chromosomes 5, 13 and 3, respectively, is currently under consideration [3]. Due to the fact that KTWS is considered as a subset of KTS and that currently there is no data on gene and chromosome aberrations for KTWS in the NCBI / GENE global gene database (Fig. 2), it could be assumed that the genes responsible for KTS are probably also responsible for KTWS.

\begin{tabular}{|c|c|c|c|}
\hline $\begin{array}{l}\text { KTWS } \\
\text { ID: } 791122\end{array}$ & $\begin{array}{l}\text { Klippel-Trenaunay- } \\
\text { Weber syndrome } \\
\text { [Homo sapiens } \\
\text { (human)] }\end{array}$ & & KTS \\
\hline $\begin{array}{l}\mathrm{O}_{\text {AGGF1 }} \\
\text { ID: } 55109\end{array}$ & $\begin{array}{l}\text { angiogenic factor } \\
\text { with G-patch and } \\
\text { FHA domains } 1 \\
\text { [Homo sapiens } \\
\text { (human)] }\end{array}$ & $\begin{array}{l}\text { Chromosome 5, } \\
\text { NC_000005.10 } \\
(77030404 . .77065234)\end{array}$ & $\begin{array}{l}\text { GPATC7, } \\
\text { GPATCH7, } \\
\text { HSU84971, } \\
\text { HUS84971, } \\
\text { VG5Q }\end{array}$ \\
\hline $\begin{array}{l}\text { PIK3CA } \\
\text { ID: } 5290\end{array}$ & $\begin{array}{l}\text { phosphatidylinositol- } \\
4,5 \text {-bisphosphate } 3- \\
\text { kinase catalytic } \\
\text { subunit alpha } \\
\text { [Homo sapiens } \\
\text { (human)] }\end{array}$ & $\begin{array}{l}\text { Chromosome 3, } \\
\text { NC_000003.12 } \\
(179148114 . .179240093)\end{array}$ & $\begin{array}{l}\text { CLAPO, } \\
\text { CLOVE, CWS5, } \\
\text { MCAP, MCM, } \\
\text { MCMTC, PI3K, } \\
\text { PI3K-alpha, } \\
\text { p110-alpha }\end{array}$ \\
\hline ID: $\frac{\text { Pik3ca }}{18706}$ & $\begin{array}{l}\text { phosphatidylinositol- } \\
4,5 \text {-bisphosphate } 3- \\
\text { kinase catalytic } \\
\text { subunit alpha [Mus } \\
\text { musculus (house } \\
\text { mouse)] }\end{array}$ & $\begin{array}{l}\text { Chromosome 3, } \\
\text { NC_000069.6 } \\
(32397059 . .32468486)\end{array}$ & $\begin{array}{l}\text { 6330412C24Rik, } \\
\text { caPI3K, p110, } \\
\text { p110alpha }\end{array}$ \\
\hline$\bigcirc_{\text {ID: }} 6654 \underline{\text { Aggf }}$ & $\begin{array}{l}\text { angiogenic factor } \\
\text { with } \mathrm{G} \text { patch and } \\
\text { FHA domains } 1 \\
\text { [Mus musculus } \\
\text { (house mouse)] }\end{array}$ & $\begin{array}{l}\text { Chromosome 13, } \\
\text { NC_000079.6 } \\
\text { (95350683..95375357, } \\
\text { complement) }\end{array}$ & $\begin{array}{l}\text { 2010009L17Rik, } \\
\text { 2310029P06Rik, } \\
\text { AW112072, } \\
\text { Peg3, VG5Q }\end{array}$ \\
\hline
\end{tabular}




\begin{tabular}{|c|c|c|c|c|c|}
\hline $\begin{array}{l}\text { soX2 } \\
\text { ID: } 6657\end{array}$ & $\begin{array}{l}\text { SRY-box } \\
\text { transcription } \\
\text { factor } 2 \text { [Homo } \\
\text { sapiens (human)] }\end{array}$ & \multicolumn{3}{|c|}{$\begin{array}{l}\text { Chromosome 3, } \\
\text { NC_000003.12 } \\
(181711925 . .181714436)\end{array}$} & $\begin{array}{l}\text { ANOP3, } \\
\text { MCOPS3 }\end{array}$ \\
\hline $\begin{array}{l}\text { BRCA2 } \\
\text { ID: } 675\end{array}$ & $\begin{array}{l}\text { BRCA2 DNA } \\
\text { repair associated } \\
\text { [Homo sapiens } \\
\text { (human)] }\end{array}$ & \multicolumn{3}{|c|}{$\begin{array}{l}\text { Chromosome 13, } \\
\text { NC_000013.11 } \\
(32315480 . .32399672)\end{array}$} & $\begin{array}{l}\text { BRCC2, } \\
\text { BROVCA2, } \\
\text { FACD, FAD, } \\
\text { FAD1, } \\
\text { FANCD, } \\
\text { FANCD1, }\end{array}$ \\
\hline $\begin{array}{l}\text { ID: } \\
\text { IERT }\end{array}$ & $\begin{array}{l}\text { telomerase } \\
\text { reverse } \\
\text { transcriptase } \\
\text { [Homo sapiens } \\
\text { (human)] }\end{array}$ & $\begin{array}{l}\text { Chromosor } \\
\text { NC_00000 } \\
(1253148 . \\
\text { complemer }\end{array}$ & $\begin{array}{l}5 \\
0 \\
95068\end{array}$ & $\begin{array}{l}\text { CMN } \\
\text { DKC } \\
\text { DKC } \\
\text { EST } \\
\text { PFB } \\
\text { TCS }\end{array}$ & $\begin{array}{l}9, \\
2, \\
4, \\
4, \\
\text { IFT1, } \\
\text { TP2. }\end{array}$ \\
\hline $\begin{array}{l}\text { HESX1 } \\
\text { ID: } 8820\end{array}$ & \multicolumn{2}{|c|}{$\begin{array}{l}\text { HESX homeobox } \\
1 \text { [Homo sapiens } \\
\text { (human)] }\end{array}$} & \multicolumn{3}{|c|}{$\begin{array}{l}\text { Chromosome 3, } \\
\text { NC_000003.12 } \\
\text { (57197838..57227643, } \\
\text { complement) }\end{array}$} \\
\hline
\end{tabular}

Figure. 3: NCBI / GENE global gene database for bilateral ocular hypoplasia.

An interesting fact is that bilateral ocular hypoplasia is encoded by different genes, some of which are located again in chromosomes number 3,5 and 13 (SOX-2, HESX-1, TERT, BRCA-2), but in different allelic regions [3]. For this reason, the possibility of a eventual "gene interlacing" / common pathogenetic link and parallel induction at the genomic level could also be considered? However, it is important to note that ophthalmic features, including optic nerve hypoplasia, can be observed in KTS, which, however, are the result of vascular anomalies, i.e However, it is important to note that ophthalmic features, including optic nerve hypoplasia, can be observed with KTS, which, however, are the result of vascular anomalies, i.e. we are talking about secondary involvement within the existing syndrome $[1,2]$. We present an interesting patient who has a primary bilateral ocular aplasia, regardless of concomitant KTS.

\section{References}

1. Junior M, Augusto $\mathrm{C}$, et al. Ophthalmological manifestation of the Klippel Trenaunay Syndrome. Rev. bras.oftalmol., Rio de Janeiro, v. 75, n. 5, p. 405-408, Oct.2016.doi;10.5935/0034-7280.20160082

2. Bothun E, Kao T, Guo Y, and Christiansen S. Bilateral optic nerve drusen and gliomas in Klippel-Trenaunay syndrome. J AAPOS. 2011; 15(1):77-79.doi: 10.1016/j.jaapos.2010.10.009.

3. Zhang T, Yao Y, Wang J, Li Y and He P et al. Haploinsufficiency of Klippel-Trenaunay syndrome gene Aggf1 inhibits developmental and pathological angiogenesis by inactivating PI3K and AKT and disrupts vascular integrity by activating VE-cadherin. Hum Mol Genet. 2016, 1; 25(23):5094-5110. doi: 10.1093/hmg/ddw273. 